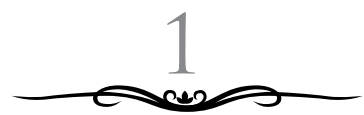

\title{
DAMPAK MEDIA SOSIAL TERHADAP PERPUSTAKAAN
}

\author{
Endang Fatmawati \\ UNDIP Semarang, Jawa Tengah, Indonesia \\ eenfat@yahoo.com
}

\begin{abstract}
Online media has penetrated in all areas including the library so the impact on the rapid flow of information. Library into the gates of knowledge so librarian most responsible for the release of information entered into the goal. Information posts from the library can be made through any type of social media application. Social media was created to enable people to communicate and connect with others. Social media has changed the way librarian in doing their jobs related to communicating with the users, how to communicate both individually and at the library level. Social media have forever changed the way interact, share, and ultimately conduct our relationships. The various information appeared like seawater unstoppable spread so users required to be wise in choosing and using them. A wave of false news more so by the presence of social media. Social media become a challenge for librarians to improve their competence with media literacy of new technology. Librarian library through a very important role as a gateway healthy information.
\end{abstract}

Keywords: library, online media, social media, social networking.

\begin{abstract}
Abstrak
Media online sudah merambah di semua bidang termasuk perpustakaan sehingga berdampak pada pesatnya arus informasi. Perpustakaan menjadi gerbang pengetahuan
\end{abstract}


sehingga pustakawanlah yang paling bertanggung jawab menjadi gawang masuk keluarnya informasi. Informasi dari perpustakaan dapat dilakukan melalui semua jenis aplikasi media sosial. Media sosial memungkinkan kita berkomunikasi dan terhubung dengan yang lain. Media sosial dapat mengubah pekerjaan pustakawan yang berhubungan dengan komunikasi dengan pemustaka, baik perseorangan maupun pada level perpustakaan. Media sosial merubah cara untuk berinteraksi, berbagi, dan menjalin hubungan. Beragam informasi muncul bagaikan air laut yang tak terbendung penyebarannya sehingga pemustaka dituntut harus bijak dalam memilih dan menggunakannya. Gelombang berita bohong semakin terasa dengan hadirnya media sosial. Media sosial menjadi tantangan bagi para pustakawan untuk meningkatkan kompetensi literasi media dengan teknologi baru. Perpustakaan melalui pustakawannya sangat berperan sebagai gerbang informasi sehat.

Kata Kunci: perpustakaan, media online, media sosial, jejaring sosial.

\section{A. Pendahuluan}

"Teknologi dari diri" sebagai perangkat - mekanis atau sebaliknya - yang memungkinkan konstruksi sosial dari identitas pribadi dengan cara mereka sendiri atau dengan bantuan orang lain, melalui operasi pada tubuh mereka sendiri, jiwa, pikiran, perilaku, dan cara bersikap, untuk mencapai tujuan tertentu: kebahagiaan, kemurnian, kebijaksanaan, atau kesempurnaan abadi (Michel Foucault).

Media online sudah merambah ke semua bidang termasuk perpustakaan. Secara umum, media online merupakan situs web yang berfungsi sebagai forum online atau sarana interaksi sosial, pergaulan, pertemanan diantara orang-orang di seluruh dunia. Segala jenis media maupun sarana komunikasi yang tersaji secara online melalui koneksi internet dapat berupa email, website, blog, media sosial, jejaring sosial, maupun aplikasi chatting. Informasi 
merupakan kebutuhan pokok setiap orang bagi pengembangan pribadi dan lingkungan sosialnya serta merupakan bagian penting bagi ketahanan nasional.

Melalui jaringan online informasi dapat diakses oleh siapapun tanpa batasan ruang dan waktu, karena hak memperoleh informasi merupakan hak asasi manusia, sementara itu keterbukaan informasi publik merupakan salah satu ciri penting negara demokratis yang menjunjung tinggi kedaulatan rakyat untuk mewujudkan penyelenggaraan negara yang baik. Perpustakaan sebagai gerbang pengetahuan, sedangkan pustakawan berperan sebagai pengawal keluar masuknya arus informasi. Disadari atau tidak bahwa dampak era digital terhadap perpustakaan dan pemustaka telah menghadirkan apa yang disebut dengan jejaring sosial (social networking). Pengertian jejaring sosial menurut English Dictionary Online $e^{1}$ yaitu:

“... the use or establishment of social networks or connections; (now esp.) the use of websites which enable users to interact with one another, find and contact people with common interests, etc".

Hal ini dimanfaatkan untuk berkomunikasi secara digital pasca 2G (teknologi generasi kedua ponsel), dengan menggunakan beberapa platform sekaligus. Selain itu, juga berbagi informasi, bertukar pengalaman, dan promosi kegiatan dengan aplikasi menggunakan media sosial. Namun dampak yang terjadi saat ini adalah munculnya berita dengan kategori fitnah, kemudian menyebarkan berita bohong (hoax) semakin merajalela dan menjadi hiasan media sosial sehari-hari. Penggunaan smartphone yang semakin banyak oleh pemustaka sangat memungkinkan untuk melakukan chatting dan beragam aktivitas di berbagai jejaring sosial dunia maya. Menyalurkan 'kecerewetan' lewat media sosial ada sisi positifnya jika isi beritanya tidak bersifat hoax. Hal ini seperti diskusi antara pustakawan yang dilakukan lewat internet dengan WA, Twitter, FB, dan media lainnya dengan saling berdiskusi secara intensif yang bersifat membangun. Pustakawan

${ }^{1}$ Oxford English Dictionary Online. 2010. "Social networking” 
dalam konteks sebagai pengelola informasi sangat berperan dalam menekan penyebaran informasi hoax.

Dalam artikel ini akan dibahas beberapa hal terkait dengan isu yang terjadi dengan hadirnya media sosial di perpustakaan, yang meliputi: pengertian media sosial, mengelola media sosial, kategori pemustaka, dampak media sosial, tips bermedia sosial, sampai peran pustakawannya.

\section{B. Pembahasan}

\section{Pengertian Media Sosial}

Media sosial (social media) disingkat medsos, terdiri dari 2 (dua) kata yang berbeda, yaitu media (alat, sarana komunikasi, perantara, penghubung), dan sosial (berkenaan dengan masyarakat atau merujuk pada cara orang berinteraksi). Kaplan \& Haenlein ${ }^{2}$ merumuskan media sosial yaitu sebuah aplikasi berbasis internet yang memungkinkan terjadinya penciptaan dan pertukaran konten yang diciptakan oleh penggunanya. Selanjutnya menurut Mayfield ${ }^{3}$ bahwa:

"social media is best understood as a group of new kinds of online media, which share most or all of the following characteristics: participation, opennes, corversation, community, connectedness".

Dibandingkan dengan media konvensional, media sosial memiliki kelebihan: begitu mudah digunakan (user friendly), menciptakan interaksi yang lebih luas, memiliki jangkauan global, siapapun dapat berbagi informasi lebih cepat secara real time, maupun dapat mengukur efektivitas informasi yang dibagi melalui respon yang muncul. Hadirnya media sosial mempengaruhi relasi antar individu. Lalu mengenai seberapa besar keuntungan kita menggunakan media sosial adalah sangat tergantung pada diri kita masing-masing.

\footnotetext{
${ }^{2}$ Kaplan, A. M. \& Haenlein, M. 2010. “Users of The World, Opportunities of Social Media”, p. 59

${ }^{3}$ Mayfield, Antony. (2008). What is social media?, p. 5
} 
Keuntungannya yang jelas lebih murah dibanding via telepon, disamping untuk menjalin silaturahmi, berbagi informasi (lebih cepat), ekspresi diri, pencitraan diri, ajang curhat, sampaipada bisnis/pemasaran online. Reitz ${ }^{4}$ menyebutkan fungsi dari media sosial, yaitu: mempertahankan identitas organisasi, kesempatan dalam membangun hubungan, kemampuan untuk mengontrol manajemen isu, dan kesempatan untuk mempromosikan CSR.

Media sosial memiliki beberapa karakteristik yang membedakan dengan media konvensional. Karakter media sosial yang disampaikan oleh Mayfield ${ }^{5}$ agak berbeda dengan yang disampaikan oleh Musser dan O’Reilly. Karakteristik media sosial menurut Musser dan O’Reilly ${ }^{6}$, antara lain:

1. Memungkinkan pengguna web untuk melakukan lebih dari sekedar menelusur informasi.

2. Memungkinkan pengguna melakukan eksekusi langsung dari browser dan kemudian mengontrol data pada platform media sosial.

3. Pengguna dapat menambah nilai konten yang diakses. Hal ini karena media sosial bersifat user friendly sehingga tidak perlu membutuhkan pengetahuan khusus untuk menggunakannya.

4. Perangkat media sosial yang desentralisasi tanpa adanya sistem kontrol.

5. Transparan dan menggunakan standar teknologi yang tumbuh pesat menjadi ekosistem terbuka, membangun

4 Reitz, A. 2012. "Social Media's Function in Organizations: A Functional Analysis Approach". Global Media Journal - Canadian Edition, Volume 5, Issue 2, pp. 41-56, available at http://www.gmj.uottawa.ca/1202/ v5i2_reitz.pdf [accessed 11 Februari 2017].

${ }^{5}$ Mayfield, A. 2008. What is social media? Available at http://www. icrossing.com/uk/sites/default/files_uk/insight_pdf_files/What $\% 20$ is $\% 20$ Social\%20Media_iCrossing_ebook.pdf [accessed 11 Februari 2017].

${ }^{6}$ Musser, J \& O’Reilly, T. 2002. Web 2.0 Principles and Pratices, O’Reilly Media Inc, available at http://oreilly.com/radar/web2report.csp [accessed 11 Februari 2017]. 
aplikasi untuk membangun data terbuka dan menggunakan komponen.

6. Muncul media sosial tidak tergantung pada aplikasi pada struktur yang ditetapkan sebelumnya.

Bagi pustakawan yang memiliki jiwa enterpreneur, maka media sosial sangat dibutuhkan keberadaannya disamping untuk kepentingan yang terkait dengan perpustakaan. Hal ini karena bisa dimanfaatkan untuk membangun jaringan terkait keperluan bisnis dan memperluas wawasan. Namun demikian jelas akan sangat berbeda manfaatnya jika hanya untuk updated status yang kurang esensial dan unggah foto selfie saja.

Untuk kebebasan untuk berkomunikasi dengan media telah diatur dalam UUD 1945 tepatnya pada Pasal 28F, yang berbunyi:

"Setiap orang berhak untuk berkomunikasi dan memperoleh informasi untuk mengembangkan pribadi dan lingkungan sosialnya, serta berhak untuk mencari, memperoleh, memiliki, menyimpan, mengolah, dan menyampaikan informasi dengan menggunakan segala jenis saluran yang tersedia".

Namun dampak kebebasan juga memunculkan kejahatan yang memang sengaja dilakukan oleh oknum dengan beragam motif. Berbagai kejahatan berbasis internet dengan penipuan di dunia maya (cyberfraud) yang marak terjadi khususnya di Indonesia, misalnya: jaringan teroris, penyalahgunaan penggunaan kartu kredit, perjudian online, pemalsuan identitas, pembobolan rekening, maupun pembajakan website. Bahkan data dari Cisco menunjukkan data yang mencengangkan, sebanyak 40\% lalu lintas cyber crime berasal dari Indonesia, disusul oleh Tiongkok sebesar 38\%. Adapun beberapa bentuk kejahatannya adalah sebagai berikut:

1. Carding, yaitu berbelanja menggunakan nomor dan identitas kartu kredit milik orang lain, yang diperoleh secara ilegal, biasanya pelaku mencuri data di internet.

2. Hacking, yaitu menerobos program komputer milik pihak lain dengan lebih fokus pada prosesnya untuk merusak dan mencuri datanya. 
3. Cracking, yaitu hacking untuk tujuan jahat, sama-sama menerobos keamanan komputer orang lain dengan lebih fokus untuk menikmati hasilnya.

4. Defacing, yaitu mengubah halaman situs/website pihak lain dengan mencuri data dan dijual kepada pihak lain.

5. Phising, yaitu kegiatan memancing pengguna komputer di internet agar mau memberikan informasi data diri pemakai (username) dan kata sandinya (password) pada suatu website yang sudah di-deface.

6. Spamming (bulk email atau junk e-mail), yaitu pengiriman berita atau iklan lewat surat elektronik yang tak dikehendaki sehingga sering disebut sebagai sampah.

7. Malware, yaitu program komputer yang mencari kelemahan dari suatu software dan biasanya untuk membobol dan merusak suatu software atau operating system, misalnya: virus, worm, trojan horse, adware, browser hijacker, dan lain sebagainya.

Penelitian yang dilakukan oleh Xie \& Stevenson ${ }^{7}$ bahwa aplikasi media sosial untuk perpustakaan digital dapat dilihat dari beberapa aspek, seperti: jenis, penempatan, perbaharuan, jenis interaksi, serta jenis peran. Lebih jelasnya saya rangkum dalam tabel berikut:

\begin{tabular}{ll}
\hline \multicolumn{1}{c}{ ASPEC } & \multicolumn{1}{c}{ EXAMPLE } \\
\hline Types of social media & $\begin{array}{l}\text { Blogs, Microblogs (twitter), Photo sharing Podcast, } \\
\text { RSS Feeds, Social networks, Video (youtube), Wikis }\end{array}$ \\
\hline $\begin{array}{l}\text { Placement of social } \\
\text { media }\end{array}$ & $\begin{array}{l}\text { Homepage instansi, Homepage perpustakaan, Top } \\
\text { (left, centre, right), Bottom (left, centre, right) }\end{array}$ \\
\hline $\begin{array}{l}\text { Updates of social } \\
\text { media }\end{array}$ & $\begin{array}{l}\text { Hourly, Daily, Weekly, Monthly, Sporadic, User- } \\
\text { based updates only, Updates not related solely to } \\
\text { digital library }\end{array}$ \\
\hline Types of interactions & $\begin{array}{l}\text { Check in, Comment, Friend, Follow, Like, Newsfeed, } \\
\text { Notifications, Post, Share, Tweet }\end{array}$ \\
\hline
\end{tabular}

7 Xie, I. and Stevenson, J. 2014. "Social media application in digital libraries". Online Information Review, Volume 38, Number 4, pp. 502-523, DOI:http://dx.doi.org/10.1108/OIR-11-2013-0261 [accessed 12 Februari 2017]. 


\begin{tabular}{ll}
\hline Types of roles & $\begin{array}{l}\text { Information, Information sharing, Marketing/ } \\
\text { promotion, Peer-to-peer connection }\end{array}$ \\
\hline
\end{tabular}

\section{Sumber: disarikan dari Xie \& Stevenson (2014)}

Media sosial bagi perpustakaan di era online seperti sekarang sangatlah penting, karena perpustakaan terus berkembang dan sebagai pusat peradaban menuju masyarakat yang cerdas. Untuk keperluan pemasaran dan promosi perpustakaan serta membangun jejaring sangat dibutuhkan. Adanya media sosial, hendaknya pustakawan harus aktif mempromosikan perpustakaan kepada masyarakat secara luas secara virtual. Ada variasi dari media sosial dan yang paling populer diterapkan di perpustakaan digital meliputi: blog, facebook, podcast, RSS feed, twitter, youtube, serta wiki. Ada aplikasi media sosial yang memiliki lebih dari satu fungsi, misalnya twitter adalah jejaring sosial situs, tetapi pada saat yang sama, twitter juga berfungsi untuk berbagi foto dan diklasifikasikan sebagai microblog.

Media sosial merupakan bentuk nyata dari media baru (new media) berbasis TIK. Kalau dahulu munculnya handphone ada istilah SMSan sekarang dengan hadirnya smartphone menjadi bergeser istilahnya yaitu WAnan. Unik memang, tapi ini terjadi pada diri kita dan pemustaka kita. Media sosial menjadi bagian dari website dan media online. Forum online ini berfungsi sebagai sarana berbagi atau bertukar infomasi dan saling berkomentar. Jenisnya antara lain:

a. Jejaring sosial pertemanan = Friendster, Facebook, Twitter, Myspace, Bebo, hi5, Google Plus, Blog, Foursquare, Path, Snapchat, Bebo, maupun jaringan sosial berorientasi bisnis (LinkedIn).

b. Aplikasi Chatting = untuk berkirim pesan, misalnya: WhatsApp, Line.

c. Share Media = memfasilitasi untuk saling berbagi informasi, misalnya: Situs berbagi video musik (YouTube), Foto (Instagram, Flickr), File (SlideShare), Wiki, Video, Crowdstorm, Feedback. 
d. Discuss Media = memfasilitasi sekelompok orang untuk melakukan obrolan dan diskusi (Skype, Google Talk, Phorum, Messenger, Yahoo! M, Video Talk); Publish (Wordpress, Wikipedia, Blog, Wikia, Digg).

e. Social Game = media sosial berupa game yang dapat dilakukan atau dimainkan bersama-sama (Koongregate, Doof, Pogo, Cafe.com).

Jika melihat pengguna internet di Indonesia, maka jumlahnya cukup besar. Lebih dari 50\% penduduk Indonesia memiliki gawai (gadget) dalam kesehariannya. Hal ini seperti yang dilansir oleh Kompas ${ }^{8}$ bahwa penetrasi digital di tengah masyarakat berlangsung sangat cepat. Selanjutnya faktor literasi masyarakat yang rendah berkorelasi dengan suburnya ladang hoax. Hal ini karena masyarakat terbiasa membaca berita dengan sepotong-potong dan jika diestimasi dengan waktu mungkin tidak lebih dari 1 menit saja. Artinya muncul budaya gegabah, jadi begitu menerima informasi lalu segera di-forward, di-share dan seterusya, sehingga tidak sempat dipikirkan dan diendapkan dahulu maksud isinya maupun diklarifikasi kebenaran isinya.

Hasil survei Asosiasi Penyelenggara Jasa Internet Indonesia (APJII) dan Polling Indonesia 2016 mencatat 132,7 juta orang atau lebih dari separuh penduduk Indonesia $(51,5 \%)$ dari total jumlah penduduk Indonesia sebesar 256,2 juta telah menggunakan internet. Jumlah pengguna internet di Indonesia tahun 2016 adalah 132,7 juta orang atau sekitar 51,5\%, kemudian pengguna internet terbanyak ternyata didominasi di pulau Jawa dengan total pengguna sebesar 86.339.350 (sekitar 65\%) dari total pengguna Internet. ${ }^{9}$

Namun demikian, walaupun jumlah pengguna internet di Indonesia telah melampaui 50\% dari total penduduk, data dari $\mathrm{CNN}^{10}$ menyebutkan bahwa masih ada $48,2 \%$ dari populasi

${ }^{8}$ KOMPAS, Selasa 7 Februari 2017, hal. 1, kol.1-4 dan hal. 15, kol. 4-7.

9 Asosiasi Penyelenggara Jasa Internet Indonesia. 2016. Infografis Penetrasi \& Perilaku Pengguna Internet Indonesia, Survei APJII 2016.

10 Cable News Network (CNN) Indonesia. 2016. Statistik 
penduduk Indonesia yang masih belum tersentuh internet. Pada Gambar 1 berikut nampak penyebaran demografi penetrasi pengguna internet di Indonesia:

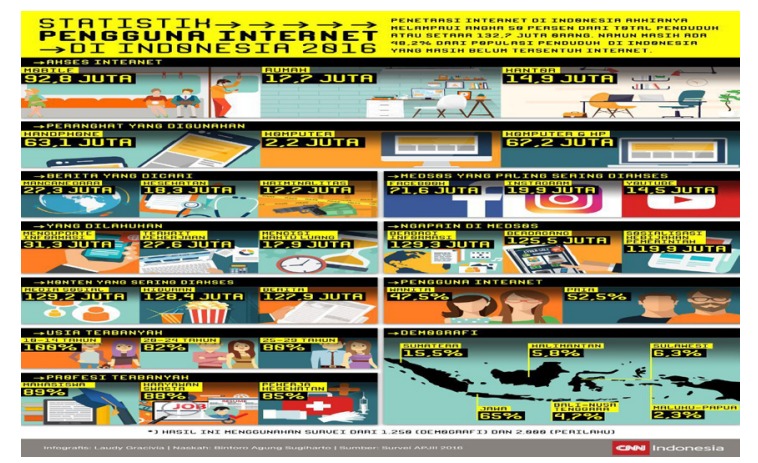

\section{Gambar 1. Demografi Penetrasi Pengguna Internet Indonesia (CNN Indonesia, 2016)}

Bagaimanapun tingginya pengguna internet di Indonesia menjadi salah satu faktor yang turut mendukung perkembangan media sosial di Indonesia, walaupun sebenarnya kalau dirunut pada sejarah penetrasi internet baru masuk di Indonesia sekitar tahun 90-an. Media sosial merupakan aplikasi real time yang digunakan untuk berinteraksi atau berjejaring sosial secara online menggunakan jaringan internet sebagai sarana berkomunikasi dan berbagi dengan orang lain. Bagaimanapun juga media sosial dilindungi dalam ranah kebebasan berpendapat yang begitu luas dan tanpa ada rambu dan jeratan regulasi. Hal ini berarti bahwa pengguna media sosial merasa lebih bebas memperoleh dan menyebarkan informasi tanpa intervensi dari pihak manapun.

Media sosial menjadi salah satu dari aplikasi yang sering digunakan oleh pengguna internet Indonesia. Data dari CNN Indonesia $^{11}$, menunjukkan bahwa konten yang sering diakses

Pengguna Internet di Indonesia. Dalam http://www.cnnindonesia.com/ teknologi/20161025185725-188-167920/statistik-pengguna-internet-diindonesia/ [accessed 11 Februari 2017].

11 Cable News Network (CNN) Indonesia. 2016. Statistik Pengguna Internet di Indonesia. Dalam http://www.cnnindonesia.com/ teknologi/20161025185725-188-167920/statistik-pengguna-internet-di- 
adalah media sosial (129,2 juta), kemudian hiburan (128,4 juta), dan berita (127,9 juta). Selanjutnya data dari APJII ${ }^{12}$ diketahui bahwa konten media sosial yang paling banyak dikunjungi adalah aplikasi facebook sebesar 71,6 juta pengguna (54\%) dan urutan kedua adalah instagram sebesar 19,9 juta pengguna (15\%). Sementara itu, web online shop menempati konten komersial yang paling banyak dikunjungi (sebesar 82,2 juta atau 62\%). Lebih jelasnya seperti pada pada Gambar 2 berikut:

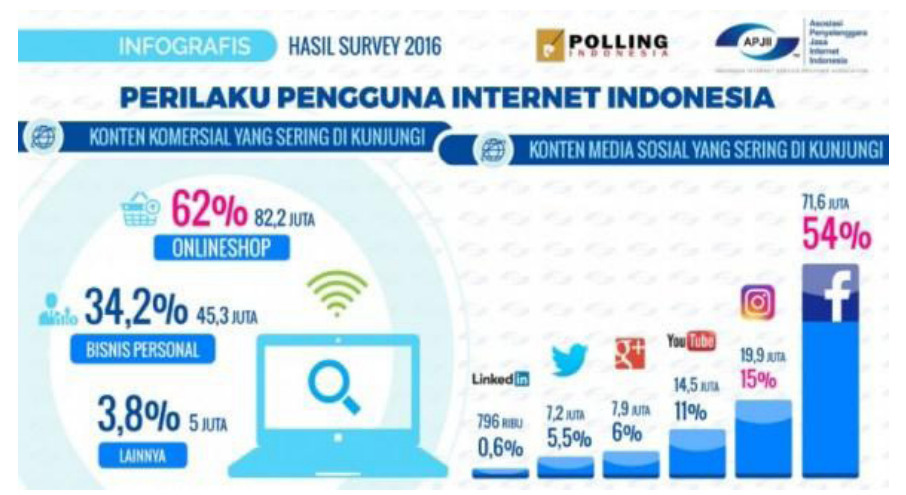

\section{Gambar 2. Konten Komersial dan Konten Media Sosial} (APJII, 2016: 25)

Aplikasimediasosialsudahmenjadibagiantidakterpisahkan dari smartphone yang rata-rata pemustaka memilikinya. Media sosial telah menjadi bagian integral perpustakaan modern dan akan menjadi kekuatan positif jika perpustakaan bisa memanfaatkannya. Jargon "Perpustakaan bermedia sosial, maka Pustakawan ada" memiliki makna mendalam bahwa kesadaran eksistensial yang merasa perpustakaan akan bisa eksis menggunakan media sosial dalam menyampaikan informasi jika didukung oleh peran pustakawannya. Mengenai sejarahnya seperti Gambar 3 berikut:

indonesia/ [accessed 11 Februari 2017].

12 Asosiasi Penyelenggara Jasa Internet Indonesia. 2016. Infografis Penetrasi \& Perilaku Pengguna Internet Indonesia, Survei APJII 2016. 


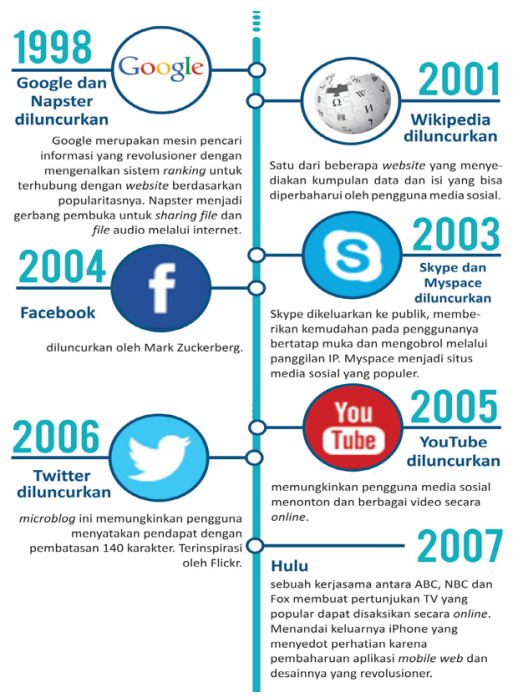

Gambar 3. Sejarah Media Sosial (1998-2007)

(Kementerian Perdagangan RI, 2014: 13)

Dalam konteks bermedia sosial maka pustakawan dapat memperlihatkan keunggulan dan keunikan perpustakaannya (misalnya: koleksi, fasilitas, informasi terbaru, poster ajakan tidak plagiat, dan yang lainnya). Informasi dapat diunggah baik itu melalui status, upload foto kegiatan perpustakaan, maupun hanya sekedar data bibliografi. Suatu contoh bagi pustakawan kreatif yang menampilkan aktivitasnya dengan menggunakan akun media sosial seperti facebook, twitter, maupun instagram, maka hal ini juga bisa memperlihatkan 'identitas' perpustakaannya seperti apa. Perpustakaan dapat mengabadikan best moment, promosi, maupun share foto kegiatan yang telah dilakukan. Salah satu indikator yang menunjukkan eksistensi pemustaka adalah dari semakin banyaknya yang memberi komentar, like, jempol maupun follower, berarti semakin bagus respon pemustakanya.

\section{Mengelola Media Sosial}

Praktik penggunaan media sosial di perpustakaan perguruan tinggi bisa membangun aktivitas berbagi pengetahuan dan meningkatkan komunikasi ilmiah. Apalagi bagi para peneliti, media sosial menjadi alat multidimensi yang memungkinkan 
untuk berbagi pengetahuan, berdiskusi, dan berkomunikasi dengan peneliti dari berbagai disiplin keilmuan. Hal ini seperti yang disampaikan oleh Wasike ${ }^{13}$ bahwa:

"Knowledge sharing is one of the motivations of scholarly communication. To the researcher, social media is a multidimensional instrument which enablesknowledgesharing to satisfy their needs in discussions and communications with others on interdisciplinary subjects".

Sungguh dibutuhkan strategi bagi pustakawan dalam mengelola akun perpustakaannya. Begitu juga untuk akun pustakawan sendiri, yang siapa tahu data pribadi kita menjadi incaran penjahat maya. Hati-hati mengunggah sesuatu di media sosial, baik itu hanya up date status, coba-coba/iseng saja, maupun foto-foto kegiatan yang sifatnya pribadi. Hal ini karena suatu saat bisa jadi bumerang bagi diri kita sendiri. Ada pihak yang tidak bertanggung jawab memanfaatkannya.

Sering kita mendengar bahwa dalam politik persaingan jabatan, ada lawan politik yang sengaja mencari titik kelemahan dengan mengunggah foto lawannya (pasalnya foto pernah diunggah yang bersangkutan beberapa tahun yang lalu) ke media sosial. Tidak disangka yang bersangkutan, di saat yang bersangkutan berjuang menggalang simpati publik menjadi wakil rakyat, namun justru diserang lawan politiknya dengan cara menyebarkan foto yang negatif tersebut. Hal ini sangat ironis karena memang terjadi di lapangan. Tidak hanya terjadi pada orang-orang biasa, namun terjadi pula pada elite politik juga, seperti kicauan mantan Presiden SBY yang menyebut bahwa penyebar hoax berkuasa dan merajalela. Kita tahu adanya komentar dari SBY tersebut spontan mengundang reaksi dari pemerintah dan berbagai pihak.

Perpustakaan perlu sekiranya memberikan pendidikan pemustaka melalui pemberdayaan pustakawannya. Saya berpendapat bahwa era media sosial saat ini, pustakawan dan

13 Wasike, J. 2013. "Social media ethical issues: role of a librarian", Library Hi Tech News, Volume 30, Number 1, pp. 8-16, DOI:http://dx.doi. org/10.1108/07419051311320922 [accessed 12 Februari 2017]. 
pemustaka harus memiliki multiple kompetensi yang terkait isu literasi, seperti: literasi informasi, literasi akademik, literasi visual, sampai pada literasi media. Untuk pemateri pendidikan pemustaka tidak harus dari pustakawan, tapi bisa mengundang pakar lintas profesi dan lebih bagus jika tempat pelaksanaannya dikondusifkan di perpustakaan. Jikalau pustakawan yang tampil, maka harus memiliki kepiawaian berbicara dan tetap rendah hati (humble). Anggaplah peserta sebagai mitra diskusi sehingga bisa sharing pengetahuan.

Pustakawan harus mampu berpikir Out of the Box, contohnya mengadakan program kegiatan bincang perpustakaan dengan materi umum di luar konteks perpustakaan. Hal ini seperti mengadakan sosialisasi dengan materi tentang media sosial, seperti: etika bermedia sosial, tips sleep hygiene tanpa gangguan smartphone, bijak berjejaring sosial, dan lain sebagainya.

Keberadaan akun-akun palsu dan situs abal-abal yang melakukan hujatan dan penyebaran berita hoax di media sosial cenderung dilakukan oleh oknum secara terstruktur dan sistematis, sehingga saya rasa perlu langkah antisipatif penegakan hukum. Hal ini untuk meningkatkan pertahanan keamanan dan menertibkan perdagangan elektronik. Mudah-mudahan rencana pemerintah Indonesia akan membentukBadan Siber Nasional (BSN) pada tahun 2017 segera terwujud. Sungguh cita-cita mulia karena dengan BSN, maka tugasnya dimungkinkan untuk mengkoordinasikan badan cyber defence yang ada di Kementerian Pertahanan, cyber intelligence di Badan Intelijen Negara (BIN), maupun cyber security di Polri. Idealnya penertiban situs-situs di dunia maya yang akan dilakukan pemerintah melalui Kementerian Komunikasi dan Informatika harus dilakukan secara transparan dan tidak diskriminatif agar jaminan kebebasan berpendapat bagi masyarakat tetap dapat dipelihara. Hal ini termasuk tindakan pemblokiran juga harus melalui mekanisme dan prosedur yang telah ditetapkan dalam konstitusi. Hal ini mengingat payung hukum dalam UU No. 14 tahun 2008 tentang Keterbukaan Informasi Publik, yang mengatur bahwa masyarakat berhak mengetahui dasar dari setiap keputusan 
yang diambil oleh lembaga pemerintah. Saya rasa pemblokiran adalah langkah yang efektif untuk mencegah akses negatif yang semakin meluas. Adanya revisi UU No. 11 Tahun 2008 tentang Informasi dan Transaksi Elektronik (ITE) hendaknya membuat masyarakat semakin bijak dalam bermedia sosial.

\section{Kategori Pemustaka}

Dalam konteks pemustaka urban dan rural tentu terpaan media online dan aplikasi yang diterapkan menjadi sangat berbeda. Untuk mahasiswa yang tinggal di kota secara umum jauh lebih terpapar daripada yang tinggal di desa. PTN dan PTS juga demikian, perguruan tinggi yang pimpinannya melek teknologi dan mempunyai pola pikir yang maju untuk perpustakaan tentu dukungan anggaran maupun infrastruktur untuk perkembangan TIK di kampusnya akan bagus. Begitu pula bagi perguruan tinggi besar dan kecil pasti juga akan berbeda penerapan teknologinya. Contoh dalam kajian Lichy ${ }^{14}$, menyampaikan bahwa mahasiswa di Prancis dan Rusia yang tinggal di desa lebih sering menggunakan media cetak, sedangkan mahasiswa yang tinggalnya di kota selalu menggunakan media online dalam akses informasi.

Terkait dengan era sosial media, maka kategori generasi pemustaka yang cocok adalah pemustaka digital natives, digital settlers dan social listening. Digital natives memang lahir di saat teknologi informasi sudah merambah dalam kehidupan mereka sehingga mengenal produk berbasis teknologi informasi sejak usia dini dan terbiasa dengan teknologi baru di saat usia mereka sedang pada masa pertumbuhan. Selain mem-posting dan meng-upload di media sosial, mereka juga merespon atau menyampaikan informasi melalui social networking. Hasil kajian yang dilakukan oleh Dickson \& Holley ${ }^{15}$ menemukan bahwa jejaring sosial yang dilakukan di

14 Lichy, J. 2012. “Towards an International Culture Gen Y Students and Sns”. Sage, 13 (2), 101-116. available at http://journals.sagepub.com/doi/ pdf/10.1177/1469787412441289 [accessed 11 Februari 2017].

${ }^{15}$ Dickson, A. and Holley, R. P. , 2010. "Social networking in academic libraries: the possibilities and the concerns", New Library World, Volume 111, Number11/12,pp.468-479,DOI:http://dx.doi.org/10.1108/03074801011094840 
perpustakaan perguruan tinggi merupakan metode efektif untuk menjangkau mahasiswa, menghargai privasinya, dan menyediakan cakupan informasi yang sama untuk semua bidang ilmu.

Dalam tulisan Topper ${ }^{16}$ tentangjejaringsosialdiperpustakaan ditunjukkan tentang pentingnya sebuah nilai perencanaan untuk langkah ke depan dan sebagai pedoman mengakses informasi. Dahulu membentuk jejaring sosial adalah harus bertemu secara fisik (face to face), namun lama kelamaan bergeser menjadi termediasi dengan teknologi (computer to computer). Bahkan saat ini hanya dengan aplikasi melalui smartphone to smartphone atau antar gawai lainnya. Selanjutnya pendapat Mitrano dalam tulisannya yang berjudul "A Wider world: youth, privacy, and social networking technologies" sebagaimana dikutip Topper ${ }^{17}$ menyatakan bahwa bentuk awal teknologi jejaring sosial seperti: online multiplayer games, bulletin boards, news group, mailing lists, maupun dating services.

Kategori pemustaka digital natives memiliki karakter digital yang terbentuk sejak usia dini dan mampu beradaptasi dengan semua perkembangan produk teknologi informasi yang baru. Digital settlers posisinya diantara digital immigrants dan digital natives, maksudnya adalah pemustaka yang lahir sebelum produk teknologi informasi baru merambah dunia, namun dalam kehidupannya selalu mengikuti dan mencoba berbagai produk teknologi informasi dalam media baru. Jadi secara fisik barangkali usianya seumuran dengan digital immigrants akan tetapi dari sisi teknologi digital pemustaka tersebut juga tidak kalah menguasai seperti halnya digital natives.

Selanjutnya ada kategori pemustaka social listening user, yaitu hanya pasif dalam social networking dan social media. Mereka

[accessed 11 Februari 2017].

16 Topper, E. F. 2007. "Social networking in libraries", New Library World, Volume 108, Number 7/8, pp. 378-380, DOI:http://dx.doi. org/10.1108/03074800710763662 [accessed 11 Februari 2017].

17 Topper, E. F. 2007. "Social networking in libraries", New Library World, Volume 108, Number 7/8, pp. 378-380, 
hanya pemerhati dan pembaca saja, mereka melakukan aktivitas hanya sekedar membaca berbagai postingan, status, dan komentar, maupun respon dari orang lain dalam suatu social network. Apalagi yang masuk di dalam anggota nama grup tetentu (group di facebook maupun whatsApp) yang namanya postingan pasti selalu mengalir terus dan saling berkelindan di berbagai grup. Jika tidak selektif bisa jadi memori HP menjadi penuh, lemot akses, dan jika dituruti maka kita akan disibukkan hanya untuk mengecek status orang lain.

Poin penting bahwa tidak selalu berarti mereka yang termasuk kategori pemustaka social listening ini kuper dan menarik diri dalam komunitas kelompok tertentu, tetapi social listening diperlukan agar pemustaka tidak tertinggal dalam berbagai informasi, berita, maupun pengetahuan yang sebelumnya belum diketahuinya. Untuk merespons dan melayani kebutuhan generasi pemustaka yang termasuk dalam kategori net generation saat ini, maka perpustakaan wajib memberikan informasi lewat akun perpustakaan di media sosial. Hal ini karena generasi pemustaka yang melek teknologi cenderung tidak senang bersandar kepada perpustakaan konvensional. Apalagi pemustaka generasi milenial (Y) yang lahir antara tahun 1981-1999 yang biasanya tidak percaya pada informasi satu arah, tidak loyal pada satu hal, lebih memilih telepon seluler daripada televisi, mempunyai akun di media sosial, tidak mau membaca media konvensional, maupun lebih tahu teknologi daripada orang tua.

\section{Dampak Media Sosial}

Fenomena "om telolet om" pernah menjadi viral dunia maya. Terlepas dari bus yang membunyikan klakson, tapi jika diambil hikmahnya untuk konteks pendekatan spiritual, maka justru viral telolet ada pesan positifnya, karena bagi siapapun yang jalannya tidak benar maka perlu diklakson "telolet" agar jalannya benar. Bagi sebagian umat muslim, terkadang karena terlalu asyik menggunakan media sosial, urusan ibadah menjadi tertunda. 
Potret masyarakat yang mulai luntur dalam melakukan amalan-amalan untuk urusan akhirat, mereka lebih tunduk pada urusan dunia media sosial yang kebenaran informasinya belum jelas. Dahulu jika kita memperhatikan orang di tempat publik adalah menunduk membaca koran, tabloid, buku, namun sekarang menunduk karena membaca pesan di smartphone, tablet, dan gawai portable lainnya. Suatu contoh saat panggilan adzan berkumandang, bukannya menyegerakan shalat namun masih sibuk membuka status di beberapa aplikasi yang diikutinya. Bagi pegawai termasuk pustakawan bisa jadi akan menurunkan produktivitas dan kinerja karena sibuk membuka pesan dari berbagai grup WA yang diikuti.

Secara umum dapat saya sampaikan dampak positif dan negatif. Untuk dampak positifnya, antara lain: memperluas jaringan antar perpustakaan; meningkatkan kompetensi pustakawan dalam mengaplikasikan media baru; mendekatkan informasi yang berada di perpustakaan lain; media penyebaran informasi yang up to date; sebagai media komunikasi antar sesama pustakawan, antara pustakawan dan pemustaka, maupun antar sesama pemustaka; sebagai media pertukaran data yang cepat dan murah; sebagai media promosi perpustakaan dan lain sebagainya.

Sementara itu, sisi negatifnya apabila media sosial ada di gawai yang dimiliki pustakawan, maka bukan hal mustahil jika ada kecenderungan untuk selalu melihat notifikasi yang masuk setiap waktu. Hal ini menyebabkan: pustakawan dengan budaya menunduk menjadikan tidak sadar akan lingkungan sekitar, relasi sosial menjadi renggang, mengurangi privacy dalam diripustakawan maupun pemustaka, menurunkan kinerja \& produktivitas pustakawan, muncul gangguan kesehatan tubuh (terutama mata) dan lain sebagainya. Selain itu, terkait dengan smartphone juga menimbulkan gangguan yang bersifat psikis, misalnya:

1. Social anxiety disorder

Kita ada perasaan cemas kalau akan ditinggalkan follower dan sering merasa jika smartphone kita berbunyi karena ada notifikasi dari media sosial 
2. Obsessive compulsive disorder-ODC

Kita tidak bisa meninggalkan smartphone walaupun cuma sebentar, bahkan ke kamar mandi juga dibawa, tidur didekatkan, kemudian saat bepergian lebih baik ketinggalan barang lainnya daripada harus ketinggalan smartphone.

3. Fear of missing out,

Kita merasa sayang jika melewatkan tidak membukabuka status orang lain, sehingga akan selalu meng-update kehidupan orang lain di sosial media.

Dari sudut pandang apa dan bagaimana perpustakaan dalam menggunakan media sosial itu perlu direnungkan agar pelaksanaannya menjadi jelas terarah. Jika untuk memperluas area jejaring dan promosi perpustakaan, maka memanfaatkan media sosial menjadi sangat penting. Bagi pemustaka di lingkungan perguruan tinggi, mohon jika belajar itu jangan hanya mengandalkan Google, termasuk belajar Al Qur'an maupun pendalaman teori dari setiap mata kuliah, karena jika tidak hatihati maka bisa terperosok ke lubang yang salah.

\section{Tips Bermedia Sosial}

Menjaga lisan tidak hanya secara fisik, namun juga ucapan melalui media sosial. Saya menghimbau kepada para pustakawan, ingatlah selalu bahwa "Salamatul insan fi hifdzil lisan", bahwa keselamatan seseorang tergantung pada menjaga/mengendalikan lisan. Entah itu gosip, fitnah, berita hoax, menerima dan membagi informasi, mengunggah status, berkirim SMS, men-tweet, berkirim gambar emoticons atau ekspresi diri, dan lain-lain hendaklah memperhatikan hal-hal sebagai berikut:

1. Melakukan konfirmasi terlebih dahulu dan memeriksa dengan teliti (tabayyun).

"Jika datang kepadamu orang fasik dengan informasi maka periksalah dengan teliti (QS. Al Hujurot: 6). Tidak asal percaya dan hendaknya diendapkan dahulu, apakah berupa fakta atau prasangka (zhan). 
Hal ini karena "Sesungguhnya prasangka tidak memberimu sedikit kebenaran (QS. An Najm: 28). Janganlah menghukum sesuatu yang belum jelas kebenarannya (prejudice), walaupun benar tetapi ghibah juga jika dibicarakan, kemudian jika salah maka akan menjadi fitnah sehingga sama-sama tidak ada pilihan. Oleh karena itu, sekiranya perlu difikir apakah perlu disebarkan/tidak, jangan-jangan menimbulkan kebencian, permusuhan, atau malah menyinggung dan menyakiti orang lain.

2. Berbicara yang baik atau memilih diam saja, jangan mudah menerima dan mengirim informasi.

3. Memperhatikan etika beinformasi (mencantumkan sumber, jangan diakui sebagai pendapatnya sendiri).

4. Jangan (memberikan data diri dengan mudah di media sosial maupun terlalu mengumbar kehidupan pribadi).

5. Tidak berbicara, mem-posting, meng-upload dan men-share konten yang memiliki unsur SARA.

6. Tidaka sembarang berkomentar bernada kebensian, permusuhan, dan provokasi di akun orang lain, karena bisa melanggar UU ITE.

7. Menghilangkan informasi hoax tanpa mengganggu kebebasan berpendapat.

8. Khusus Group WA pokoknya fokus saja untuk menjalin silaturahim, senantiasa amar ma'ruf nahi munkar, dan menambah cakrawala pengetahuan. Beberapa tips agar meminimalisir konflik antar anggota grup WA yaitu:

a. Memahami latar belakang anggota grup (pendidikan, status sosial);

b. Menerima tipe orang dalam grup (seriusan, agamis, suka homor, vokal);

c. Memaklumi isi pesan/komentar yang diberikan (sekalipun hanya respon like);

d. Cuex dengan tingkat keaktifan anggota (social listening dan pemerhati saja);

e. Jangan mudah terpancing/terpengaruh postingan (delete 
jika tidak suka dan jika salah maka wajib diluruskan);

f. Menggunakan bahasa yang tepat dan perlu menempatkan diri dengan siapa kita berinteraksi;

g. Menghargai dan menghormati postingan dan komentar orang lain;

h. Empan papan (dalam berucap maupun berkomentar).

Media sosial diaplikasikan di perpustakaan untuk memungkinkan pemustaka berkomunikasi dan terhubung dengan pihak lain. Selain untuk berkomunikasi dengan pemustaka dan berjejaring dengan perpustakaan lain, media sosial juga sebagai media pemasaran dan promosi perpustakaan. Informasi dari perpustakaan dapat dilakukan melalui semua jenis aplikasi media sosial, contohnya pesan informatif yang berupa perpustakaan tutup layanan lebih awal, pemadaman listrik, jaringan ada gangguan, dan lain sebagainya. Informasi tersebut bisa disebarluaskan melalui aplikasi media sosial yang digunakan di perpustakaan yang dimunculkan di news feed pemustaka, seperti Facebook, Twitter, maupun RSS feed.

Aplikasi media sosial dapat memberikan fungsi yang berbeda dalam hal pengelolaan, promosi, dan cara berkomunikasi dengan pemustakanya. Beberapa aplikasi bisa saja memainkan peran yang lebih efektif daripada aplikasi lainnya. Misalnya blog dapat berbagi informasi, koneksi peer-to-peer, pemasaran, maupun promosi. Jadi aplikasi media sosial menjadi pendekatan efektif jika bisa diterapkan di perpustakaan untuk mempromosikan layanan yang ada dan berinteraksi dengan pemustakanya. Untuk mewujudkan ini membutuhkan peran pustakawan.

\section{Tantangan Pustakawan}

Perpustakaan dalam era perkembangan sekarang ini memerlukan tenaga-tenaga yang mumpuni di bidang perpustakaan yang mampu beradaptasi terhadap kebutuhan baik secara teknis maupun pemikiran pengembangan ke depan. ${ }^{18}$ Sementara itu,

${ }^{18}$ Wiji Suwarno, "Mengembangkan SDM Perpustakaan Dalam Rangka Menuju World Class University” Libraria, Vol. 4, No, 1, Juni 2016, hal. 108. 
Dickson dan Holley ${ }^{19}$ menyebutkan bahwa pustakawan perguruan tinggi harus proaktif dalam jejaring sosial dan berpartisipasi aktif dalam prosesnya.

Jejaring sosial yang merupakan bagian dari media sosial untuk bersosialisasi dan berinteraksi yang berupa pemanfaatan media sosial untuk membangun berbagai jaringan, baik itu pertemanan, bisnis, aksi demonstrasi, dan yang lainnya menuntut pustakawan harus memiliki literasi media digital terkait dengan media baru.

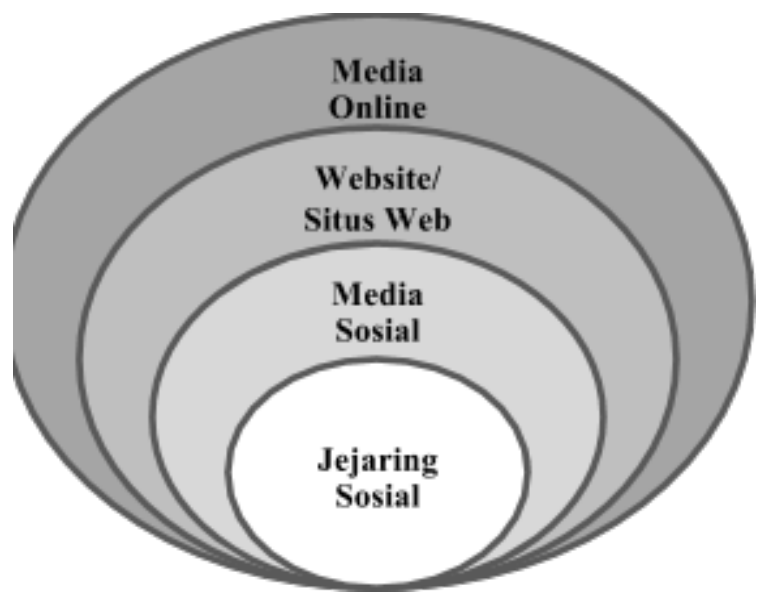

Gambar 4. Cakupan Media Online (modifikasi penulis, 2016)

Keterangan:

Gambar 4 berikut menunjukkan bahwa bagian yang terbesar adalah media online, kemudian salah satu jenis media online adalah website/situs web, lalu media sosial menjadi bagian dari media online dan website, dan yang terakhir bagian dari media sosial yang disebut dengan jejaring sosial.

Saat menerima informasi dari jejaring sosial maka yang dibutuhkan adalah bukan hanya bisa membaca tapi juga bisa literasi membaca. Perpustakaan harus menjadi gerbang informasi sehat

${ }^{19}$ Dickson, A. and Holley, R. P. , 2010. "Social networking in academic libraries: the possibilities and the concerns", New Library World, Volume 111, Number 11/12, pp. 468-479. 
yang mencerdaskan. Pustakawan dalam mengambil keputusan harus didukung dengan data, analisa, dan fakta yang ada, sehingga keputusan yang diambil lebih akurat.

Pustakawan generasi tua bisa timbul cultural sock dalam berinteraksi dengan media sosial. Hal ini karena mereka tidak bisa beradaptasi menghadapi perubahan lingkungan perpustakaan yang berbasis teknologi. Terlepas dari sisi usia, saya menghimbau, ustakawan ayolah bangkit, semangat bersama untuk memerangi hoax yang beredar.

Pustakawan perlu mengajari bahwa jika ada berita maka perlu dipelajari dahulu dengan menelusuri berita tersebut. Intinya jangan terlalu cepat di-liked atau bahkan di-share begitu saja biar seperti "pahlawan" seolah-olah yang menginformasikan pertama kali. Jangan sampai pustakawan diperalat oleh orang yang mengunggah sesuatu di media sosial yang sengaja mencari keuntungan sepihak. Biasanya orang seperti ini hanya memikirkan perut sendiri dengan prinsip yang penting meraih royalti dari Google jika berita yang disebarkan ternyata banyak yang like dan share. Oleh karena itu, kita harus hati-hati, paling tidak perlu membaca dahulu isinya dan mengendapkan maksud berita yang disampaikan oleh orang tersebut.

Bagaimanapun media sosial lahir sebagai dampak dari kemajuan TIK. Media sosial menjadi fenomena luar biasa bagi sebuah perpustakaan sehingga harus bisa memaksimalkan penggunaan media. Jika perpustakaan zaman dulu yang masih tradisional, untuk menyebarkan informasi masih manual. Hal ini seperti menempel daftar uku baru di papan pengumuman, mengirim surat melalui pos untuk tagihan keterlambatan buku, dan kegiatan lainnya. Saat ini bisa dilakukan dengan menggunakan media sosial yang jenisnya sangat beragam. Agar media sosial tidak menebar masalah maka berikut sarannya:

1. Pustakawan harus bersikap bijak dan profesional terhadap maraknya penyebaran informasi yang tidak dapat dipertanggungjawabkan.

2. Pustakawan harus bisa menjadi teladan literasi informasi 
kepada masyarakat dengan berbasis fakta dan data empiris yang valid.

3. Pustakawan harus cerdas menggunakan media sosial melalui kompetensi literasi media dari proses memahami, menganalisis, menyaring informasi yang dibutuhkan, kemudian menafsirkan makna sampai dengan memahami informasi yang diterima.

Namun yang menjadi masalah salah satunya adalah belum adanya standar atau aturan baku bagaimana pustakawan mengunggah informasi melalui aplikasi media sosial, baik dalam hal mempromosikan perpustakaan secara digital maupun dalam membuat koneksi. Begitupun dalam mendesain situs web perpustakaan, setiap perpustakaan fakultas dalam satu perguruan tinggipun juga belum semuanya seragam dan terintegrasi datanya dalam satu website.

Menjadi tantangan untuk membangun komunikasi 2 arah antara pustakawan dan pemustaka, karena interaksi diantara mereka dapat menghasilkan informasi baru yang lebih akurat. Namun demikian, meskipun media sosial telah memainkan peran penting dalam membangun perpustakaan digital, ada peran utama lainnya terkait pendidikan pemustaka. Peran ini untuk memberikan gambaran perpustakaan digital, mengajari pemustaka bagaimana menggunakan perpustakaan digital, memperkenalkan fitur yang berbeda dari perpustakaan digital, dan merekomendasikan perpustakaan digital lainnya yang berbeda berdasarkan format maupun kriteria lainnya.

Persaingan yang semakin kompetitif menuntut pustakawan memiliki keunggulan kompetensi dan harus selalui update terhadap perubahan teknologi informasi yang merambah ke perpustakaan. Melalui program diskusi lintas profesi yang diselenggarakan oleh perpustakan, maka pustakawan bisa bekerja sama dengan profesi lain. Seperti pakar/ahli TI yang kredibel dan kompeten di bidang media sosial, lalu duduk bersama menjadi pemateri dan mengundang civitas akademik untuk berdiskusi bersama. 
Media untuk mensosialisasikan cara memilah berita yang benar sehingga pustakawan wajib membentengi diri dari informasi yang beredar luas di dunia maya. Langkah ini sebagai strategi memerangi hoax saya rasa. Bukannya tidak boleh menyampaikan pendapat, kritikan, dan menulis di media jejaring sosial, namun satu hal yang perlu diperhatikan adalah mengedepankan etika bermedia sosial. Marilah berpegang pada semboyan "Iman dan ines (internet aman dan internet sehat)" sehingga fenomena gegar budaya terkait dampak negatif bermedia sosial yang terjadi di masyarakat harus dicarikan solusi.

\section{Simpulan}

Media sosial merupakan sarana komunikasi melalui internet yang memungkinkan terjadinya interaksi sosial. Pemustaka saat ini memiliki kecenderungan yang tinggi dalam mengakses informasi melalui perangkat digital (digital devices). Perpustakaan yang memanfaatkan media sosial akan mudah dalam melakukan sharing informasi. Satu hal yang perlu diingat oleh pustakawan adalah menggunakan akun dengan bijak dan lebih berhati-hati karena saat ini marak sekali tindak kejahatan yang dilakukan di media sosial. Pustakawan harus kreatif memanfaatkan media sosial untuk mengembangkan perpustakaan yang dikelolanya, disamping mempunyai semangat untuk mengedukasi kepada pemustaka sehingga memunculkan kesadaran untuk mengatasi penyebaran hoax yang meresahkan. Selain itu, pustakawan juga wajib menumbuhkan budaya literasi informasi kepada pemustakanya. Hal ini untuk mengkritisi dan mencari kebenaran dari informasi yang diterima melalui media sosial. 


\section{DAFTAR PUSTAKA}

Asosiasi Penyelenggara Jasa Internet Indonesia. 2016. Infografis Penetrasi \& Perilaku Pengguna Internet Indonesia, Survei APJII 2016.

Badan Siber digabung dengan Lembaga Sandi Negara: Kejahatan Berbasis Internet Tinggi. Suara Merdeka, Kamis 5 Januari 2017, hal. 1, kol. 1-2).

Cable News Network (CNN) Indonesia. 2016. Statistik Pengguna Internet di Indonesia. Dalam http://www.cnnindonesia.com/ teknologi/20161025185725-188-167920/statistik-penggunainternet-di-indonesia/ [accessed 11 Februari 2017].

Dickson, A. and Holley, R. P. , 2010. "Social networking in academic libraries: the possibilities and the concerns", New Library World, Volume 111, Number 11/12, pp. 468-479, DOI:http:// dx.doi.org/10.1108/03074801011094840 [accessed 11 Februari 2017].

Hati-hati Dengan Informasi!. Iklan yang dipersempahkan oleh Surya University dan Badan Nasional Penanggulangan Teroris (share WA, koleksi pribadi).

Kaplan, A. M. \& Haenlein, M. 2010. “Users of The World, Opportunities of Social Media”, Business Horizons, 53, pp. 59-68. available at https://www.slideshare.net/escpexchange/kaplan-haenleinusers-of-the-world-unite-the-challenges-and-opportunitiesof-social-media [accessed 12 Februari 2017].

Lichy, J. 2012. "Towards an International Culture Gen Y Students and Sns". Sage, 13 (2), 101-116. available at http://journals. sagepub.com/doi/pdf/10.1177/1469787412441289 [accessed 11 Februari 2017].

Literasi Rendah Ladang "Hoax” Warga Membaca Berita Tak Sampai 1 Menit. KOMPAS, Selasa 7 Februari 2017, hal. 1, kol.1-4 dan hal. 15, kol. 4-7.

Mayfield, A. 2008. What is social media? Available at http://www. icrossing.com/uk/sites/default/files_uk/insight_pdf_files/ What\%20is\%20Social\%20Media_iCrossing_ebook.pdf [accessed 11 Februari 2017]. 
Musser, J \& O’Reilly, T. 2002. Web 2.0 Principles and Pratices, O’Reilly Media Inc, available at http://oreilly.com/radar/web2report. csp [accessed 11 Februari 2017].

Oxford English Dictionary Online. 2010. "Social networking", available at http://www.oed.com/ [accessed 112 Februari 2017].

Reitz, A. 2012. "Social Media’s Function in Organizations: A Functional Analysis Approach". Global Media Journal - Canadian Edition, Volume 5, Issue 2, pp. 41-56, available at http://www.gmj. uottawa.ca/1202/v5i2_reitz.pdf [accessed 11 Februari 2017].

Suwarno, W. 2016. "Mengembangkan SDM Perpustakaan Dalam Rangka Menuju World Class University". Jurnal Perpustakaan LIBRARIA STAIN Kudus, Vol. 4, No. 1, Juni, hlm. 105-126, DOI: http://dx.doi.org/10.21043/libraria.v4i1 [accessed 12 Februari 2017].

Tim Pusat Humas Kementerian Perdagangan RI. 2014. Panduan Optimalisasi Media Sosial Untuk Kementerian Perdagangan RI. Jakarta: Pusat Hubungan Masyarakat Kementerian Perdagangan RI.

Topper, E. F. 2007. "Social networking in libraries", New Library World, Volume 108, Number 7/8, pp. 378-380, DOI:http:// dx.doi.org/10.1108/03074800710763662 [accessed 11 Februari 2017].

Undang-Undang Dasar Negara Republik Indonesia Tahun 1945.

Undang-Undang RI Nomor 11 Tahun 2008 tentang Informasi dan Transaksi Elektronik. Tersedia di http://peraturan-pemerintahpp-pdf.blogspot.co.id/2012/10/uu-no-11-tahun-2008informasi-transaksi.html [diakses 11 Januari 2017].

Wasike, J. 2013. "Social media ethical issues: role of a librarian”, Library Hi Tech News, Volume 30, Number 1, pp. 8-16, DOI:http:// dx.doi.org/10.1108/07419051311320922 [accessed 12 Februari 2017].

Xie, I. and Stevenson, J. 2014. "Social media application in digital libraries". Online Information Review, Volume 38, Number 4, pp. 502-523, DOI:http://dx.doi.org/10.1108/OIR-11-20130261 [accessed 12 Februari 2017]. 
Halaman ini bukan sengaja dikosongkan 